Pacific, and four in Latin America-and include the firstever CLP Team Awards granted to projects in Costa Rica, Botswana and Tajikistan. The successful projects will undertake research and practical conservation action to save a range of threatened species, many of which are categorized as Vulnerable, Endangered or Critically Endangered on the IUCN Red List. These include the Vulnerable snow leopard Panthera uncia in India and Tajikistan, the Endangered white-bellied pangolin Phataginus tricuspis in Nigeria, the Critically Endangered El Rincon stream frog Pleurodema somuncurense in Argentina, and the Vulnerable red-breasted goose Branta ruficollis in Kazakhstan. Other projects focus on threatened but relatively neglected flora and fauna, including endemic invertebrate species living in the dark karst caves of western Georgia, important seagrass ecosystems in Costa Rica, and the species-rich mecrusse forest in Mozambique.

The teams will use a variety of research methods, such as GPS-tagging and camera traps. For example, GPS-tagging will be used to monitor the last known population of the Vulnerable short-tailed roundleaf bat Hipposideros curtus in Nigeria, and camera traps will track elusive carnivores, such as the Endangered dhole Cuon alpinus, through the forest reserves of north-east Bangladesh. Many teams will conduct outreach activities to engage local communities in long-lasting conservation solutions. For example, the recipients of this year's top prize, the Conservation Leadership Award (worth USD 50,000), will train 30 conservation champions and engage 50 local schools in a long-term plan to save the snow leopard in the trans-Himalaya, India.

CLP is now inviting applications to its 2021 Team Awards (see p. 750). To view a full list of the funded projects, visit conservationleadershipprogramme.org/our-projects/latestprojects-2020. CLP was initiated in 1985 and is a partnership between BirdLife International, Fauna \& Flora International and the Wildlife Conservation Society.

KATE ToINTON (ㅇ orcid.org/0000-0002-7106-8606)

Fauna \& Flora International, Cambridge, UK

E-mail kate.tointon@fauna-flora.org

\section{Decline of whale shark deaths documented by citizen scientist network along the Venezuelan Caribbean coast}

At the beginning of this century, observations of the Endangered whale shark Rhincodon typus in Venezuelan waters comprised 20 opportunistic records spanning the previous 51 years (Romero et al., 2000, Biodiversity 1, 1115), suggesting they were present infrequently. A decade later, there were sightings year-round, distributed all along the coast. News of killings of whale sharks also became more frequent. In 2014, the Centro para la Investigación de Tiburones de Venezuela began to systematically document whale shark observations and engage fishers linked to shark encounters. They interviewed 222 people from 17 towns, spanning Maracaibo in the west to Margarita Island in the east. Reports included 142 sightings and 21 deaths of whale sharks during 2014-2017, the latter by entanglement in nets, harpooning or other capture methods. Although most encounters were opportunistic or incidental, they generally lead to the killing of sharks and the sale of their fins.

In 2016-2020 the organization visited the 17 coastal towns where reports were more frequent. Firstly, they contacted community leaders and fishers connected to shark kills, built personal relationships, developed trust, and explained the work of the organization. After one or two visits, workshops at schools, fisher cooperatives or local businesses expanded the visibility of and interest in the project. An invitation to share information on social media followed. Whale shark sightings now reach the organization within minutes. Fishers film untangling and releasing of sharks instead of killing them. Others film themselves swimming with whale sharks. Diving operators offer whale shark watching tours, increasing their value from a one-time sale of fins to repeat visits with tourists.

The clearest success indicator, however, is a sharp decline in shark killing. Prior to October 2017, interviews documented 21 shark kills. In contrast, during 2018-2020, after implementation of workshops, relationship building, and establishment of the social media network, no whale shark killings were reported. Although underreporting is possible, it seems likely that the news would reach the organization, in particular as news of captures of other shark species rapidly spread. The evidence collected through this citizen scientist network suggests that the whale sharks seen are mostly juveniles (with a mean length of c. $7 \mathrm{~m}$ ), and appear in a number of localities along the Venezuelan coast. Reports have mentioned the presence of 1-10 sharks simultaneously and during several months. Additional field data would facilitate estimation of seasonality and abundance. Although past records suggest whale sharks were only present occasionally along the Venezuelan coast, they are now a common occurrence and perhaps are here to stay.

LEONARDO SÁNCHEZ (৫ orcid.org/0000-0001-6898-2117), YURASI BRICEÑO (৫ orcid.org/0000-0002-7670-1992) and RafaEL TAVARES (๑ orcid.org/0000-0003-4185-1357) Centro de Ecología, Instituto Venezolano de Investigaciones Científicas, Caracas, Venezuela; and Centro para la Investigación de Tiburones de Venezuela, Caracas, Venezuela

DeNí Ramírez-MaCías (๑ orcid.org/0000-0003-0293-9444)

Tiburón Ballena México, Conexiones Terramar, La Paz, Baja California, México

Jon PAUl RodRíguez (๑ orcid.org/0000-0001-5019-2870) Centro de Ecología, Instituto Venezolano de Investigaciones 
Científicas; IUCN Species Survival Commission, Gland, Switzerland; and Provita, Caracas, Venezuela

E-mail jonpaul.rodriguez@gmail.com

\section{Rediscovery of Rhododendron adenosum in south-west China}

Rhododendron adenosum was categorized as Extinct in the Wild both in the Red List of China's Biodiversity-Higher Plants Volume in 2013 and by Qin et al. (2017, Biodiversity Science, 25, 745-757). Other than the specimens collected by Joseph Charles Francis Rock in 1929 (Davidian, 1978, The Quarterly Bulletin of the American Rhododendron Society, 32, 81-85), the species had not been collected in the type location in the Kulu Mountains in Muli county, south-west Sichuan, although four specimens of Rhodode$n$ dron aff. adenosum were collected in 1984 and 2008 in the Luoji Mountains (c. $130 \mathrm{~km}$ from the type location) in Puge county, south-west Sichuan. These four specimens did not, however, have flowers, precluding definitive identification.

With the support of the Second Qinghai-Tibetan Plateau Integrated Scientific Expedition Project (2019QZKKo502), the Biodiversity Survey and Assessment Project of the Ministry of Ecology and Environment of China $\left(2019 \mathrm{HJ}_{2096001006)}\right.$ and the Science and Technology Basic Resources Investigation Program of China (2017FY10010o), field investigations were conducted in May 2020 in both the Luoji Mountains and the type location in the Kulu Mountains. In the Luoji Mountains we confirmed that the specimens of $R$. aff. adenosum were wrongly identified, as they had a campaniform rather than infundibuliform floral shape and a different number of flowers per inflorescence ( $>8$ vs $4-8$ in $R$. adenosum). During 2 days in the Kulu mountains, however, we rediscovered one individual of $R$. adenosum. As there could be additional individuals in the region, we intend to survey the surrounding mountains for the species.

As only one individual $R$. adenosum is currently known it should be categorized as Critically Endangered on the IUCN Red List and as a Plant Species with an Extremely Small Population (Ma et al., 2013, Biodiversity and Conservation, 22, 803-809). In addition to field surveys, propagation experiments will be performed once seeds have been collected in the autumn, and we are discussing with local nature reserves ways to protect the single known individual.

GANG YAO (๑ orcid.org/0000-0002-3628-7088), DetUAN LIU, WeIBANG SUn and YoNGPENG MA Key Laboratory for Plant Diversity and Biogeography of East Asia, Chinese Academy of Sciences, Yunnan Key Laboratory for Integrative Conservation of Plant Species with Extremely Small
Populations, Kunming, Yunnan, China

E-mail mayongpeng@mail.kib.ac.cn

\section{Natural remedies for Covid-19 as a driver of the illegal wildlife trade}

The Covid-19 crisis has highlighted the importance of connections between wildlife and the emergence of novel pandemic diseases in humans (Zhou et al., 2020, Nature, 579, 270-273). The wildlife trade is hypothesized to have played a role in the origins of the current pandemic, resulting in calls for restrictions on the legal wildlife trade, and greater enforcement against the illegal wildlife trade, on public health grounds. There is also speculation about how the pandemic might affect the illegal wildlife trade by making consumption of wildlife products less socially acceptable, or because lockdown measures and travel restrictions may hamper effective regulation of the illegal wildlife trade. Here we highlight a case where Covid-19 is increasing demand for illegal wildlife trade products used as perceived natural disease remedies, drawing on long-term monitoring of the illegal wildlife trade in the northern Caspian Sea.

The illegal wildlife trade in the Caspian region is a significant environmental threat, particularly unregulated illegal fishing targeting the six native Caspian sturgeon species, all of which are Critically Endangered, for their meat and roe (caviar), and for the endemic, Endangered, Caspian seal Pusa caspica. Seals are deliberately targeted and caught as sturgeon fisheries bycatch (Dmitrieva et al., 2013, PLOS ONE, 8, e67074; Ermolin \& Svolkinas, 2018, Marine Policy, $87,284-290$ ). Their pelts are used in the fur trade, and other body parts in traditional medicine. Seal blubber is rendered for oil, which is used as a general health tonic in the Caspian region, as are rendered fats from sturgeons, bears, badgers, wolves and other species (Dmitrieva et al., 2013, op. cit.; L. Svolkinas et al., unpubl. data). Targeting seals and trading in their products is illegal, but compared to other illegal wildlife trade products such as elephant ivory, the trade is not strongly regulated and is not fully clandestine. Fishermen typically sell seal carcasses to middlemen, who render the blubber and wholesale the resulting oil to retailers, with the final product traded openly in regional street marketplaces selling food and household goods.

Our long-term qualitative and quantitative monitoring of marketplaces in the Russian region of Dagestan, in the northern Caspian, shows a trade in seal and sturgeon oil of at least 1,00o 1 per year. Seal oil is considered particularly effective in treating respiratory diseases, including bronchitis, asthma, sinusitis, coughing, colds, pneumonia and tuberculosis. Since the arrival of Covid-19 in the region in March 2020, eight interviews undertaken by LS with key actors in the wildlife oil trade revealed that demand has risen 